\title{
Amino acid chronology of the Lower Pleistocene deposits of Venta Micena (Orce, Granada, Andalusia, Spain)
}

\author{
T. TORRES, J. F. LLAMAS, L. CANOIRA, P. GARCÍA-ALONSO, A. GARCÍA- \\ CORTÉS and H. MANSILLA \\ Escuela Técnica Superior de Ingenieros de Minas de Madrid, Rios Rosas 21, 28003 Madrid, Spain
}

\begin{abstract}
This paper deals with a model adjustment for the estimation of age by means of amino acid racemization analysis. Two model families were obtained on the basis of the different genera of molluscs analysed, and were applied to a palaeontological site located in the Cúllar-Baza basin: "Venta Micena" (Orce, Granada). The analytical results obtained from the study of fossil gastropods have provided a very coherent average dating of $983 \pm 58 \mathrm{Ky}$, this coinciding to a large extent with the most widespread palaeontological, geological and stratigraphical datings for the site. There is, however, no agreement with certain recent theories that situate Venta Micena chronologically at the PliocenePleistocene boundary (ca. 1.6 My) or before. The validity of the dating fit was tested on the basis of another classical palaeontological site, Cúllar-Baza, where a coherent dating of $441 \pm 27 \mathrm{Ky}$ was obtained.
\end{abstract}

\section{INTRODUCTION}

One of the most important problems involved in Pleistocene palaeoenvironmental and palaeoclimatological studies in Spain, and other parts of the world, is that of placing the observations on a chronostratigraphical scale allowing the velocity or isochrony of the processes to be established. Traditionally, relative dating has been accomplished through geomorphological, palaeontological and archaeological studies in which forms, fossils and artifacts were placed on the stratigraphical scale according to (more or less) subjective analysis, i.e. the relative topographical level of fluvial terraces or glacial moraines, the evolutionary stage of fossil remains, according to an assumed velocity of evolution or the morphological characteristics of stone artifacts. Obviously these methods do not work accurately because in most cases there is in fact a feedback process: forms and deposits are used to place fossil and archaeological remains on the chronostratigraphical scale and later provide the clue for dating of the processes.

Radiometric $s . l$. methods $\left({ }^{14} \mathrm{C}\right.$, U-series, $\mathrm{K} / \mathrm{Ar}$, ESR, TL...) are particularly useful tools for dating and are widely used in spite of the range method limitations; however, the most frequent problem is related to the possibility of finding samples for dating purposes (weight or nature). The amino acid racemization dating method provides certain advantages: only minor sampling processes are required ( $80 \mathrm{mg}$ maximum) and a wide group of materials are available for dating, e.g. shells from mollusca
(Goodfriend, 1987; Wehmiller, 1993), foraminifera (Wehmiller, 1993), ostracoda (Torres et al., 1995) and eggs (Meyer, 1992); bones and teeth (Bada et al., 1973a; Marzin, 1990; Elster et al., 1991), wood (Rutter and Vlahos, 1988), speleothemes (Lauritzen et al., 1994), or even rocks and soft sediments (Hearty et al., 1992).

The amino acid analysis of fossils was initiated many years ago (Abelson, 1954) and has since been continued by many researchers (Hare, 1969, 1971; Bada and Protchs, 1973; Bada and Schroeder, 1972; Miller and Hare, 1975). Today, amino acid racemization ratio analysis makes it possible to determine the palaeoclimatological data of a region (Bada et al., 1973b; Wehmiller, 1993). Amino acid racemization analysis also allows aminostratigraphy (Miller and Hare, 1980) and aminochronology to be established. Aminostratigraphy consists of arranging geological sites into a sequence on the basis of observed clusters of racemization ratios, established using representatives of one zoological genus. This method is an excellent tool for the correlation of sea level oscillation-linked deposits-marine and fluvial terraces indicative of warm and stable climate periods (Miller and Mangerud, 1985; Kaufman, 1992; Hearty et al, 1992)-and is especially useful for the determination of neotectonics affecting Pleistocene deposits (Dumas et al., 1988). In some cases, and mainly where almost continuous sedimentation has taken place, as in the CúllarBaza Basin, it is necessary to produce numericalage results, the most common being age-calibrated 
$\left({ }^{14} \mathrm{C}\right.$ or U-series) results (Goodfriend, 1987; Dumas et al., 1988; Hearty et al., 1992; Wehmiller, 1993).

Some years ago, Venta Micena, a small-holding located close to Orce in Granada, was widely mentioned in the mass media as a result of a controversial finding of human/non-human remains (Gibert et al., 1989, 1992b). It is not our objective here to get involved in palaeoanthropological questions, but rather to place this palaeontological site on a Pleistocene time-scale using the amino acid racemization dating method. This site, along with many others in the Cúllar-Baza Basin, was dated using this method during a lengthy dating campaign carried out for drawing up of the "Instituto Tecnológico Geominero de España" 1:50000 geological map (Torres, 1995).

\section{EXPERIMENTAL}

Geographical situation and palaeontological-geological settings

Venta Micena is a well-known paleontological site of Upper Villafranchian age (Fig. 1) located in the Guadix-Baza Basin. This basin consists of a long, narrow tectonically controlled depression, the major axis of which is oriented in a NE-SW direction. The Guadix-Baza Basin constitutes an exception to the behaviour of Iberian Peninsula
Pleistocene basins: since at the end of Pliocene times they were all working under an incision-dominated regime, and in spite of short-term alluvial platform building, the erosion controlled by falling sea level was the origin of incomplete stratigraphical sections with alluvial or lacustrine terraced deposits, representing only warm (stable) intervals. During the Pliocene and most of the Pleistocene, the Guadix-Baza Basin operated as a classic endorheic basin, and there was stacking of a thick, almost continuous alluvial-lacustrine-palustrine sequence. The continuity of the Guadix-Baza Basin's Pliocene-Pleistocene geological record, and the large number of palaeontological localities preserved constitute a remarkable exception. Some authors (Anadón et al., 1987; Agustí, 1984; Alberdi et al., 1989) have established numerous chronostratigraphical sequences based on palaeontological data but without numerical dating.

Pliocene-Pleistocene sediments appear at the SW limit of the basin and at its northern boundary (ITGE, 1989). Lower Pleistocene deposits are well represented in the central part, whereas midPleistocene materials are to be found at its southern limit. The Orce site has been wrongly placed in a Middle Pleistocene dated outcrop.

The Pleistocene sedimentation of the Orce (Venta Micena) area (Fig. 2) consists of fine-grained detri-

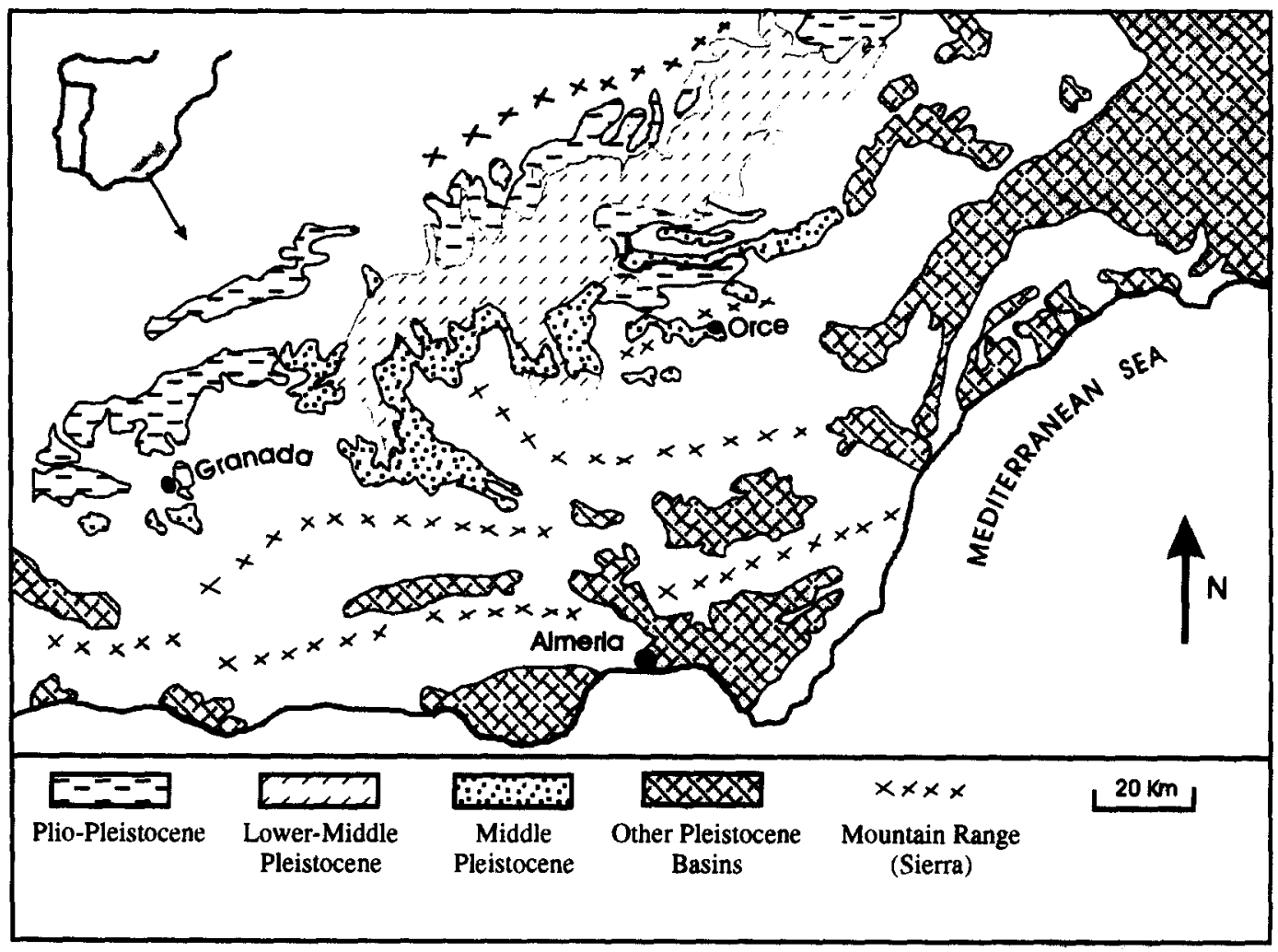

Fig. 1. Geographical and geological situation of Orce (Venta Micena) area (ITGE, 1989, modified). 


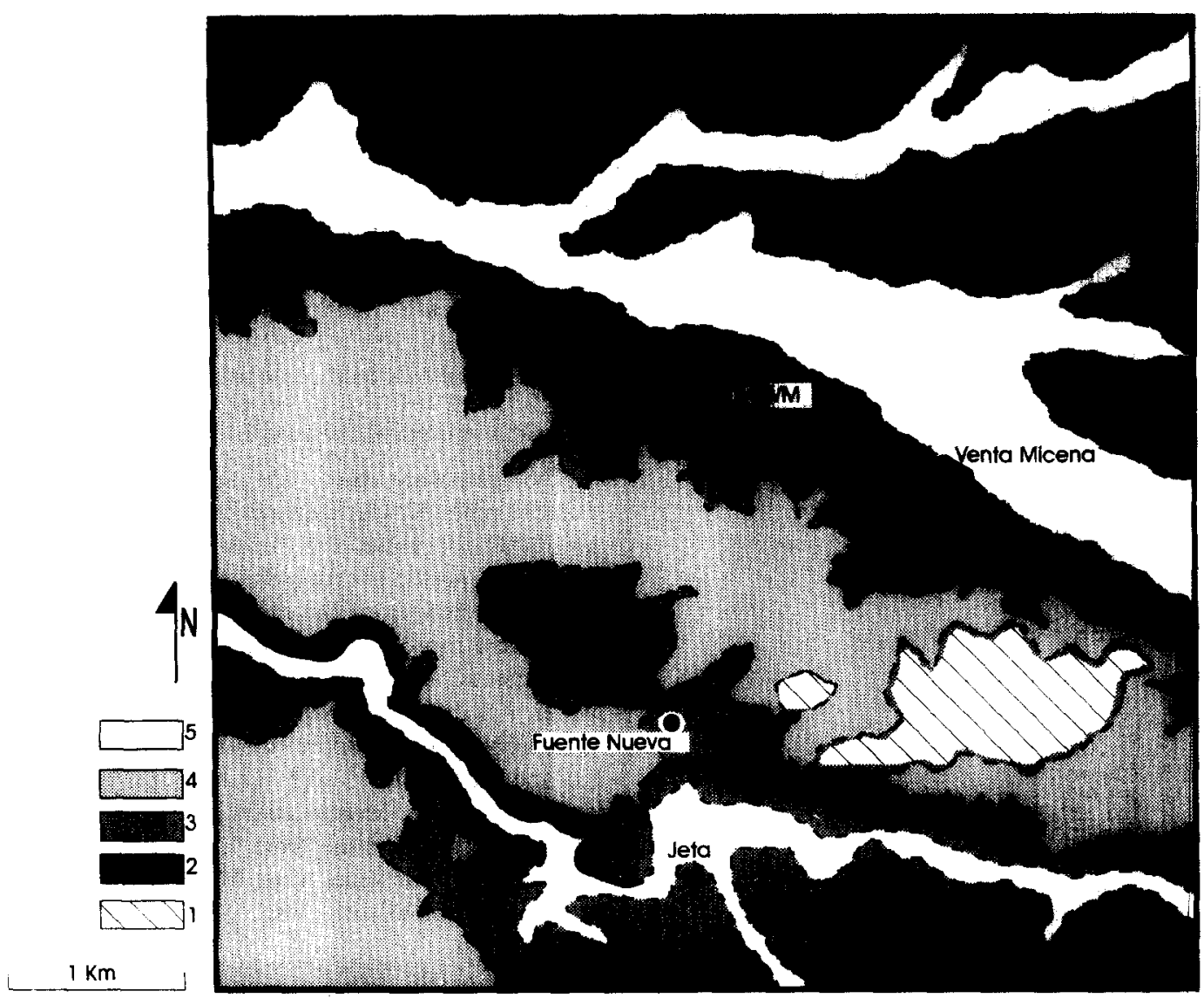

Fig. 2. Geology of the Venta Micena (VM) site (Soria et al., 1987, modified). (1) Mesozoic rock threshold; (2) fluvial-alluvial fan Pleistocene deposits; (3) palustrine-lacustrine carbonate deposits with Venta Micena (VM) palaeontological site; (4) Middle and Upper Pleistocene alluvial deposits; (5) Holocene deposits.

tal deposits at the lower part (Soria et al., 1987), followed by carbonate deposits of lacustrine origin. The lower-middle Pleistocene sediments were unconformably capped with recent gravels of alluvial origin. Mesozoic limestone outcrops acted as local thresholds during Pleistocene deposition. The bottoms of the valleys are filled with recent (Holocene) deposits

The Venta Micena section (Anadón et al., 1987) (Fig. 3) may be described as follows:

(a) dolomitic marls, dolostones and channelled gravel and sand;

(b) lutites and marls with abundant organic debris containing foraminifera, gastropoda and ostracoda, that have been sampled for amino acid racemization dating;

(c) slightly sandy lutitic limestones - the Venta Micena palaeontological site appears at the top of this stratum;

(d) partially covered, lutitic limestones and marls, dolostones and dolomitic marls-channelled gravel and sand are common; (e) nodulous lutitic limestones and limestones with gastropoda casts.

The genesis of the Venta Micena palaeontological site (c) may be interpreted as a marginal deposit of the Cúllar-Baza Basin which occurred during a lacustrine expansion event overlapping a previous mud flat [(a) and (b)]; this lacustrine environment was temporarily interrupted by channelled deposits (d).

The Venta Micena vertebrate association is made up of the following: Ursidae (Ursus etruscus), Canidae (Canis etruscus mosbachensis, Cuon priscus, Vulpes praeglacialis, Xenocyon sp.), Felidae (Homotherium latidens, Megantereon cultridens adroveri, Lynx sp., Panthera cf. gombaszogensis), Hienidae (Pachycrocuta brevirostris ruizi), Perissodactyla (Equus stenonis, Dicerorhinus etruscus, Hippopotamus incognitus), Proboscidea (Archidiskodon meridionalis) and Artiodactyla (Megaceros solhiacus, Cervus (?) elaphoides, Preaeovivos sp., Capra alba, Soergelia minor, Bison sp.), as well as the controversial Homo sp. remains. There are also rodent and lagomorph remains 


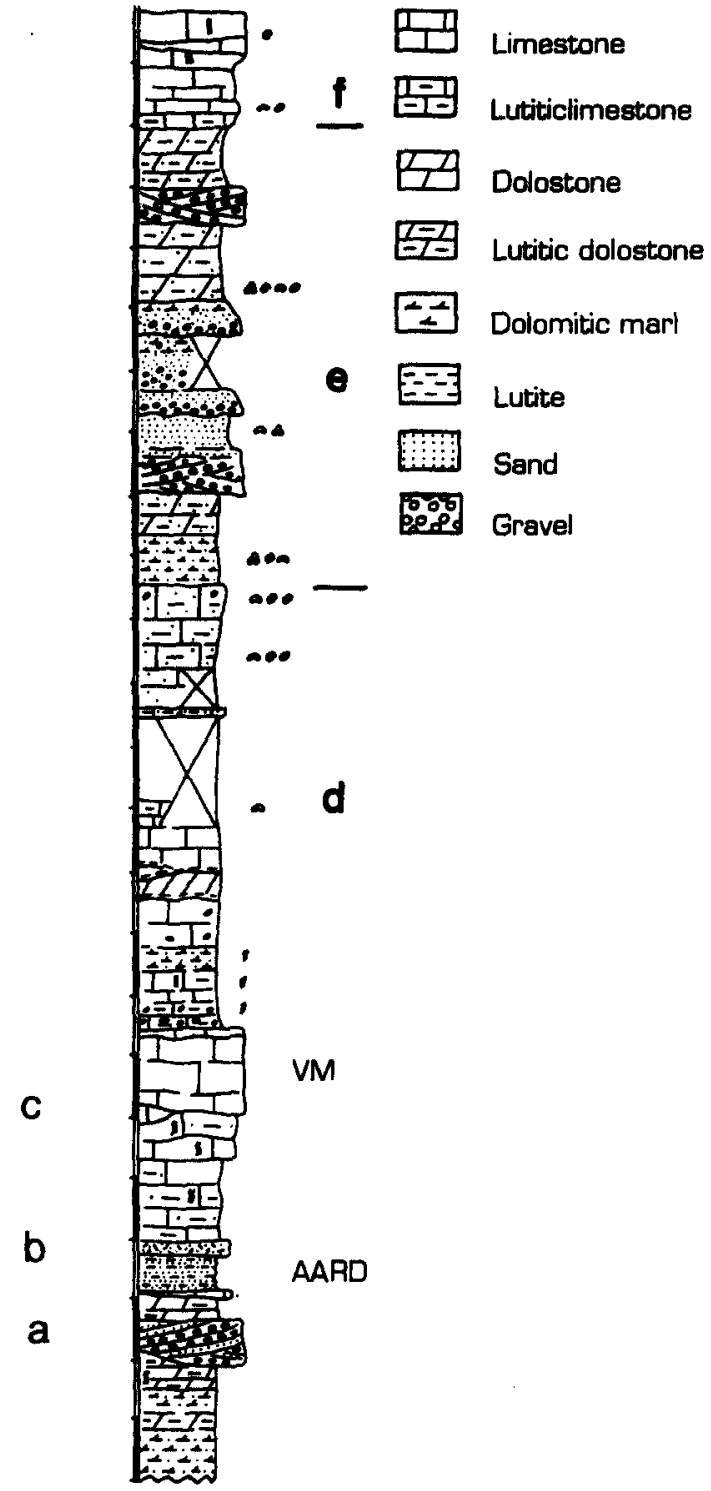

Fig. 3. Stratigraphical section of Venta Micena area (Anadón et al., 1987, modified). VM fossil mammals bearing strata. AARD sampled bed for amino acid racemization dating.

(Agustí et al. (1987)): Allophaiomys pliocaenicus, Castillomys crusafonti, Apodemus aff. mystacinus, Eliomis intermedius, Hystrix major and Prolagus cf. calpensis; and many mollusca genera: Melanoides, Melanopsis, Pomatias, Hydrobia, Mercuria, Hauffenia, Bithynia, Planorbis, Anisus, Gyraulus, Armiger, Ancylus, Acroloxus, Lymnaea, Cochlicopa, Vertigo, Pupilla, Helicella and Pisidium, cf. Robles et al. (1987). Foraminifera and crustacea are also frequent.

According to palaeontological assemblages, and to the geomorphological characteristics and palaeomagnetism of the area, Venta Micena (Alberdi $e t$ al., 1989) was dated near 1.3 My. Later (Gibert et al., 1992a) an age of $1.6 \mathrm{My}$ was established.

\section{Sampling}

A 5-kg sample was taken from a lutitic stratum located immediately below the Venta Micena fossiliferous horizon (Fig. 3). Gastropoda extraction was accomplished in accordance with the established process (Torres et al., 1994). Twenty-three individual samples were picked out from the sieved sample and analysed: they proved to be six Gastropoda indet. opercula (Bithynia sp.), three Radix (Lymnaea) sp., one Planorbis sp., one Bithynia sp. and 12 Fragmenta indet. (probably Bithynia sp.)

Sample preparation and analysis

The glassware used for analysis (except the Pasteur pipettes) was cleaned by baking in an oven at $500^{\circ} \mathrm{C}$ for about $2 \mathrm{~h}$. Eppendorf plastic micro test tubes, plastic micropipette tips and Pasteur pipettes were new from the factory. Teflon liners and septa were thoroughly washed with petroleum ether and acetone and rinsed three times with ultraclean water. All the water used in the analysis was Milli$\mathrm{Q}$ quality from Millipore. Concentrated hydrofluoric and hydrochloric acids and trifluoroacetic acid anhydride were Merck analytical grade. Thionyl chloride was purchased from Fluka AG. Isopropyl alcohol and $n$-hexane were Merck HPLC grade, and dichloromethane was Merck spectroscopy grade.

All the shells used for amino acid racemization analysis were thoroughly cleaned by a combination of ultrasonication and mechanical cleaning with a dental drill, and rinsed thoroughly with deionized water, $2 \mathrm{~N}$ hydrochloric acid and again with deionized water. Hydrolysis of ca. $80 \mathrm{mg}$ of shell was carried out in a mixture of $12 \mathrm{~N}$ hydrochloric acid $\left(2.9 \mu \mathrm{mg}^{-1}\right)$ and $6 \mathrm{~N}$ hydrochloric acid $(100 \mu \mathrm{l})$, in test tubes with Teflon-lined screw caps closed in an atmosphere of nitrogen, in a heating block at $100^{\circ} \mathrm{C}$ for $20 \mathrm{~h}$. Desalting was accomplished in conical $1.5 \mathrm{ml}$ Eppendorf plastic micro test tubes with caps, with concentrated hydrofluoric acid added $\left(1.25 \mu \mathrm{l} \mathrm{mg}^{-1}\right.$ of sample), this being mixed with a mechanical Vortex shaker, and centrifuged for $4 \mathrm{~min}$ in an Eppendorf centrifuge. The supernatant was transferred to new $1.5 \mathrm{ml}$ Eppendorf micro test tubes, frozen in liquid nitrogen, and vacuum dried in a plastic desiccator. Samples were redissolved with $80 \mu$ ldistilled water, mixed in the Vortex shaker, centrifuged for a few seconds to ensure the deposition of all the droplets, and then transferred to $2 \mathrm{ml}$ glass vials with screw caps and Teflon-lined septa. Water was evaporated at vacuum from the vials in the plastic desiccator, the caps not being tightly closed.

The first amino acid derivatization step consisted of essterification with $250 \mu \mathrm{l}$ of $3 \mathrm{M}$ thionyl chloride in isopropanol. The vials were tightly closed in a nitrogen atmosphere and left to react on the heating block at $100^{\circ} \mathrm{C}$ for just $1 \mathrm{~h}$. The tops of the vials 
were then unscrewed (but not removed) in a hood and vacuum dried in a plastic desiccator just to the point of dryness. The second derivatization step consisted of $N$-trifluoroacetylation with $150 \mu \mathrm{l}$ of trifluoroacetic acid anhydride $(25 \%$ in dichloromethane). The vials were tightly closed in a nitrogen atmosphere and heated at $100^{\circ} \mathrm{C}$ for just $5 \mathrm{~min}$ on the heating block. They were subsequently allowed to cool and opened in a hood, where the dichloromethane solvent and the unreacted trifluoroacetic acid anhydride were evaporated under a gentle flow of nitrogen. Later the samples were dissolved in $125 \mu$ of $n$-hexane, shaken in the vortex, and most of the $n$-hexane evaporated in a stream of nitrogen to a final volume of $15-25 \mu \mathrm{l}$, then being transferred to $150 \mu \mathrm{l}$ injection vials.

One $\mu 1$ of sample was injected into a HewlettPackard 5890 gas chromatograph. The injection port was kept at $215^{\circ} \mathrm{C}$ and set for splitless mode for the first $75 \mathrm{~s}$, at the beginning of which the sample was injected, and later set to split mode. We used helium as the carrier gas at a head column pressure of $5.8 \mathrm{psi}$, and a Chirasil-Val fused silica column $(25 \mathrm{~m} \times 0.39 \mathrm{~mm} \times 0.25 \mathrm{~mm})$ from Chrompack. The programme we used was as follows: $50^{\circ} \mathrm{C}$ (1 min), heat at $40^{\circ} \mathrm{C} \mathrm{min}{ }^{-1}$ to $115^{\circ} \mathrm{C}$, remaining at $115^{\circ} \mathrm{C}$ for $12 \mathrm{~min}$, heating at $3^{\circ} \mathrm{C} \mathrm{min}^{-1}$ to $190^{\circ} \mathrm{C}$, remaining at $190^{\circ} \mathrm{C}$ for $10 \mathrm{~min}$, cooling down to $50^{\circ} \mathrm{C}$ and remaining at this temperature between runs $\left(80^{\circ} \mathrm{C}\right.$ if the time between runs is longer, typically overnight). The detector was a FID set at $300^{\circ} \mathrm{C}$. Integration of the peak areas was carried out using the PEAK96 integration program from Hewlett-Packard, which runs on a PC computer. 44 shows a typical gas chromatogram of a sample. The sensitivity limits of the method may be fixed

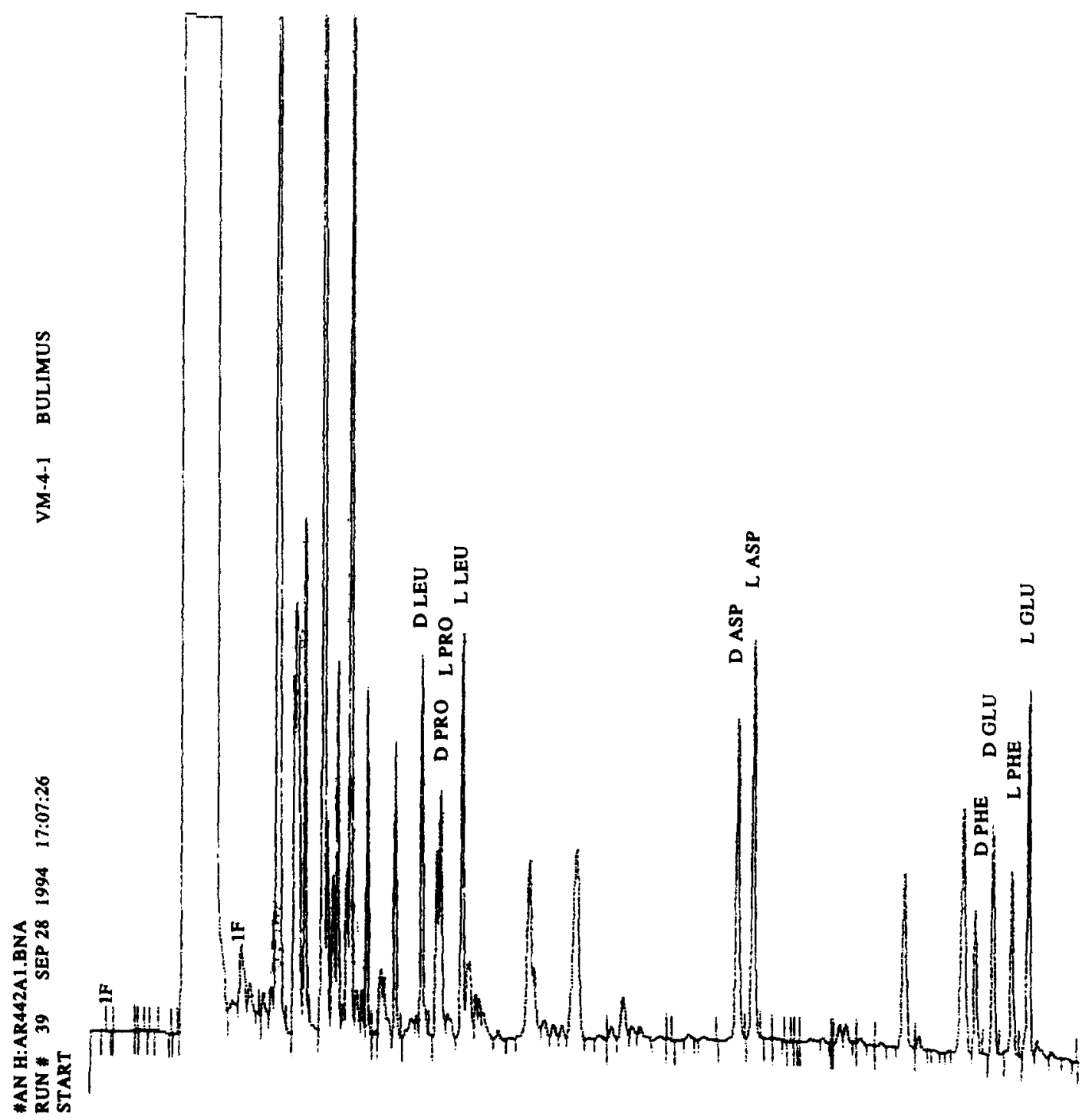

Fig. 4. Typical chromatogram from a Bulimus sp. sample from Venta Micena. 
Table 1 . Comparision of $\mathrm{D} / \mathrm{L}$ ratios between the interlaboratory results exercise and the results obtained by the amino acid racemization laboratory of E.T.S.I., Minas

\begin{tabular}{lcccc}
\hline & & \multicolumn{3}{c}{ D/L [sample (powder)] } \\
\cline { 3 - 5 } Amino acid & & ILC-A & ILC-B & ILC-C \\
\hline A/I & ILR & $0.212 \pm 0.072$ & $0.54 \pm 0.0162$ & $1.215 \pm 0.030$ \\
& LAB & 0.180 & 0.650 & 1.245 \\
PRO & ILR & $0.278 \pm 0.068$ & $0.595 \pm 0.210$ & $0.81 \pm 0.26$ \\
& LAB & 0.195 & 0.507 & 0.786 \\
LEU & ILR & $0.196 \pm 0.042$ & $0.497 \pm 0.098$ & $0.833 \pm 0.086$ \\
& LAB & 0.182 & 0.444 & 0.849 \\
ASP & ILR & $0.378 \pm 0.056$ & $0.705 \pm 0.056$ & $0.894 \pm 0.158$ \\
& LAB & 0.373 & 0.728 & 0.914 \\
PHE & ILR & $0.239 \pm 0.040$ & $0.583 \pm 0.059$ & $0.873 \pm 0.178$ \\
& LAB & 0.220 & 0.608 & 0.885 \\
GLU & ILR & $0.203 \pm 0.022$ & $0.432 \pm 0.034$ & $0.849 \pm 0.070$ \\
& LAB & 0.185 & 0.426 & 0.832 \\
\hline
\end{tabular}

ILR $=$ Interlaboratory results (confidence interval was calculated as $2 \sigma$ ).

LAB = laboratory E.T.S.I., Minas.

either in accordance with the racemization induced by the method (1-5\%, Table 2, "Today" row) or with the minimum concentration of amino acid detected, which is not a limiting factor (it depends on the age of the samples, since it affects the more recent samples in which the D-amino acid might not be detected). In all the samples analysed to date this problem has been solved by weighing a larger amount of the sample.

\section{Dating method calibration}

After setting up the analytical method in our laboratory, we worked to obtain an external validation of the method in order to control any kind of systematic error that might introduce a bias in the results. Three samples from an interlaboratory amino acid racemization exercise (Wehmiller, 1984) were also analysed: ILC-A (Saxidomus sp. ca. $50 \mathrm{Ky}$ ), ILC-B (Mercenaria sp. between 100 and $250 \mathrm{Ky}$ ) and ILC-C (Mercenaria sp. ca $1.000 \mathrm{Ky}$ ). These samples were analysed by 11 laboratories in an exercise of interlaboratory control. The lack of bias and the validity of the process fit provided by our laboratory were confirmed (Table 1).

Samples of molluscs from U/Th method dated Pleistocene fluvial travertine terraces in the Priego area (Torres et al., 1994) were collected, prepared and analysed. The age of the sampled terraces ranged between 6 and $113 \mathrm{Ky}$. In order to calculate the racemization induced during sample preparation, seven samples of gastropods collected live were also prepared and analysed. With a view to covering older geological records, $\mathrm{D} / \mathrm{L}$ amino acid ratios from 100 to $250 \mathrm{Ky}$ and ca. $1000 \mathrm{Ky}$ old localities (Wehmiller, 1984) were also used.

Spurious results were observed during interpretation of chromatographic analysis of the samples from Priego: anomalous $\mathrm{D} / \mathrm{L}$ ratios in samples from the same stratigraphic level (travertine terrace). All the observed deviations appeared as an excess of Damino acids and seemed to be related to the observed algae-fungi mat covering some of the sampled gastropod shells. Some bacteria have Damino acids in their cellular walls (Leive and Davis, 1980) and algae and fungi mats are usual bacteria housers. By the time Venta Micena was sampled, we had already modified our recovery process in order to reduce the danger of contamination: the samples were obtained from deeper parts of the strata where there is no influence by the atmosphere and sunlight. In order to avoid the influence of the spurious values, a previous single regression analysis of the $D$ - and $L$-amino acid pairs in the samples was performed. Table 2 shows the average ratios of racemization of Priego samples.

Finally, prediction models were calculated using a set of $30 \mathrm{U} / \mathrm{Th}$-dated samples from Priego: 21 freshwater gastropods, six terrestrial gastropods and three freshwater pelecipoda, as well as three samples of an interlaboratory comparison exercise (Wehmiller, 1984). The racemization models are based on a first-order reversible reaction (Bada and

Table 2. Average $\mathrm{D} / \mathrm{L}$ ratios of mollusc samples from U/Th-dated travertine terraces in Priego (Cuenca, Central Spain)

\begin{tabular}{lccccc}
\hline AGE average (U/Th) & A/I & Leu D/L & Asp D/L & Phe D/L & Glu D/L \\
\hline Today & $0.000 \pm 0.000$ & $0.008 \pm 0.0002$ & $0.051 \pm 0.008$ & $0.019 \pm 0.011$ & $0.016 \pm 0.012$ \\
6.000 & & $0.041 \pm 0.008$ & $0.215 \pm 0.051$ & $0.029 \pm 0.044$ & $0.028 \pm 0.022$ \\
12.500 & $0.149 \pm 0.078$ & $0.071 \pm 0.018$ & $0.257 \pm 0.019$ & $0.079 \pm 0.009$ & $0.070 \pm 0.006$ \\
20.000 & & $0.133 \pm 0.009$ & $0.346 \pm 0.040$ & $0.121 \pm 0.031$ & $0.105 \pm 0.013$ \\
105.000 & $0.237 \pm 0.016$ & $0.423 \pm 0.026$ & $0.594 \pm 0.026$ & $0.479 \pm 0.040$ & $0.252 \pm 0.031$ \\
\hline
\end{tabular}


Protchs, 1973; Schroeder and Bada, 1976; Bada, 1985), the algorithms being based on a time squareroot $(\sqrt{ } t)$ adjustment (Goodfriend, 1987). This would appear to be justified since its use stabilizes the variance of the error that, in the case of time $(t)$ adjustment, becomes progressively greater with growing age samples.

The models obtained are as follows:

LEU $\sqrt{ } t=(1.17 \pm 0.62)+(11.38 \pm 0.88)$ $\times \ln \{[1+(D / L)] /[1-(D / L)]\}$, correlation coefficient $=0.9774(n=33)$

$$
\text { ASP } \begin{aligned}
\sqrt{ } t= & (-2.17 \pm 1.02)+(10.02 \pm 0.85) \\
& \times \ln \{[1+(\mathrm{D} / \mathrm{L})] /[1-(\mathrm{D} / \mathrm{L})]\} \\
& \text { correlation coefficient }=0.9740(n=32)
\end{aligned}
$$

$$
\begin{aligned}
\text { PHE } \sqrt{ } t= & (0.99 \pm 0.78)+(10.26 \pm 0.74) \\
& \times \ln \{[1+(\mathrm{D} / \mathrm{L})] /[1-(\mathrm{D} / \mathrm{L})]\} \\
& \text { correlation coefficient }=0.9798(n=34)
\end{aligned}
$$

$$
\begin{aligned}
\text { GLU } \sqrt{ } t= & (2.16 \pm 0.65)+(12.44 \pm 0.82) \\
& \times \ln \{[1+(\mathrm{D} / \mathrm{L})] /[1-(\mathrm{D} / \mathrm{L})]\}, \\
& \text { correlation coefficient }=0.9816(n=36)
\end{aligned}
$$

The algorithm selected for the isoleucine epimerization model, following the adjustment of different models, was the one commonly proposed by numerous authors (Mitterer, 1975; Goodfriend and Mitterer, 1988; Goodfriend and Meyer, 1991). In this case the best fit was obtained through time $(t)$ adjustment (c.c. 0.9872) rather than time squareroot (c.c. 0.9533 ). The model is as follows:

$$
\begin{aligned}
\mathrm{A} / \mathrm{I} t= & (-34.99 \pm 25.8)+(267.14 \pm 20.32) \\
& \times \ln \{0.565 /[0.565-(\mathrm{A} / \mathrm{I}) /(1+\mathrm{A} / \mathrm{I})]\} \\
& \text { correlation coefficient }=0.9872(n=20)
\end{aligned}
$$

Although the final equilibrium state is affected only by temperature, for the Ile/Alo epimerization reaction it demonstrated the existence of a relationship in Foraminifera between racemization percentages, age and the current mean annual temperature (CMAT) (Wehmiller, 1984). In our study, we have determined the CMAT for the areas of Priego (Torres et al., 1994) and Redueña (Llamas et al., 1995), which are climatologically similar to the zone under study, a CMAT of $11-14^{\circ} \mathrm{C}$ having been found. Thus, it has been considered that the same models would be applicable. As regards the type of fossils under study, the initial results pointed to the existence of differences between amino acid kinetics depending on the genera of mollusca analysed. These differences were more marked in the oldest samples analysed. In 10 samples of ancient freshwater gastropoda (Planorbis sp. and Radix sp.) from Priego (Torres et al., 1994) this effect was very marked for glutamic acid but negligible for leucine. A poor correlation between the racemization ratios of different amino acids might be explained in terms of early diagenesis (Goodfriend, 1991), e.g. the loss of the most easily hydrolyzable amino acid from the terminal protein chains, aspartic acid, might be reflected in lower $\mathrm{D} / \mathrm{L}$ ratios, this apparently being uncorrelated with the higher $\mathrm{D} / \mathrm{L}$ ratios of the less easily hydrolyzable amino acids, such as isoleucine.

Ten individual samples from the Priego area were dated according to the $\mathrm{D} / \mathrm{L}$ leucine ratios, and an average value of $733 \pm 140 \mathrm{ky}$ was obtained. For the Priego area a current mean annual temperature (CMAT) of between 11 and $14^{\circ} \mathrm{C}$ was obtained. These values were coherent with those corresponding to this geographical location, and the CMAT was used according to the Wehmiller (1993) criteria. From our point of view, temperature might affect only the final Alo/Ile equilibrium stage. According to these results, other algorithm families were adjusted using only Planorbys sp. and Radix sp. sample results, the adjusted models being as follows:

$$
\begin{aligned}
\text { LEU } \sqrt{ } t= & (0.94 \pm 0.63)+(11.81 \pm 0.70) \\
& \times \ln \{[1+(\mathrm{D} / \mathrm{L})] /[1-(\mathrm{D} / \mathrm{L})]\}, \\
& \text { correlation coefficient }=0.9870(n=32) \\
\text { ASP } \sqrt{ } t= & (-3.34 \pm 2.31)+(12.38 \pm 2.24) \\
& \times \ln \{[1+(\mathrm{D} / \mathrm{L})] /[1-(\mathrm{D} / \mathrm{L})]\}, \\
& \text { correlation coefficient }=0.9050(n=29) \\
\text { PHE } \sqrt{ } t= & (0.48 \pm 2.88)+(15.64 \pm 3.71) \\
& \times \ln \{[1+(\mathrm{D} / \mathrm{L})] /[1-(\mathrm{D} / \mathrm{L})]\}, \\
& \text { correlation coefficient }=0.8304(n=34) \\
\text { GLU } \sqrt{ } t= & (0.33 \pm 1.44)+(21.93 \pm 2.48) \\
& \times \ln \{[1+(\mathrm{D} / \mathrm{L})] /[1-(\mathrm{D} / \mathrm{L})]\}, \\
& \text { correlation coefficient }=0.9476(n=37)
\end{aligned}
$$

In this case the best model found for Alo/Lle epimerization was the square-root of time $(\sqrt{ } t)$ adjusted (c.c. 0.9495). Time ( $t$ ) adjustment had a lower correlation cofficient value (c.c. 0.9359).

$$
\begin{aligned}
\mathrm{A} / \mathrm{I} \sqrt{ } t= & (-0.02 \pm 1.42)+(21.85 \pm 2.31) \\
& \times \ln \{0.565 /[0.565-(\mathrm{A} / \mathrm{I}) /(1+\mathrm{A} / \mathrm{I})]\}, \\
& \text { correlation coefficient }=0.9495(n=21)
\end{aligned}
$$

\section{RESULTS AND DISCUSSION}

\section{Veñta Micena}

At Venta Micena, only 21 analytical results were obtained from the 23 original samples, two being lost during the sample preparation process. The 


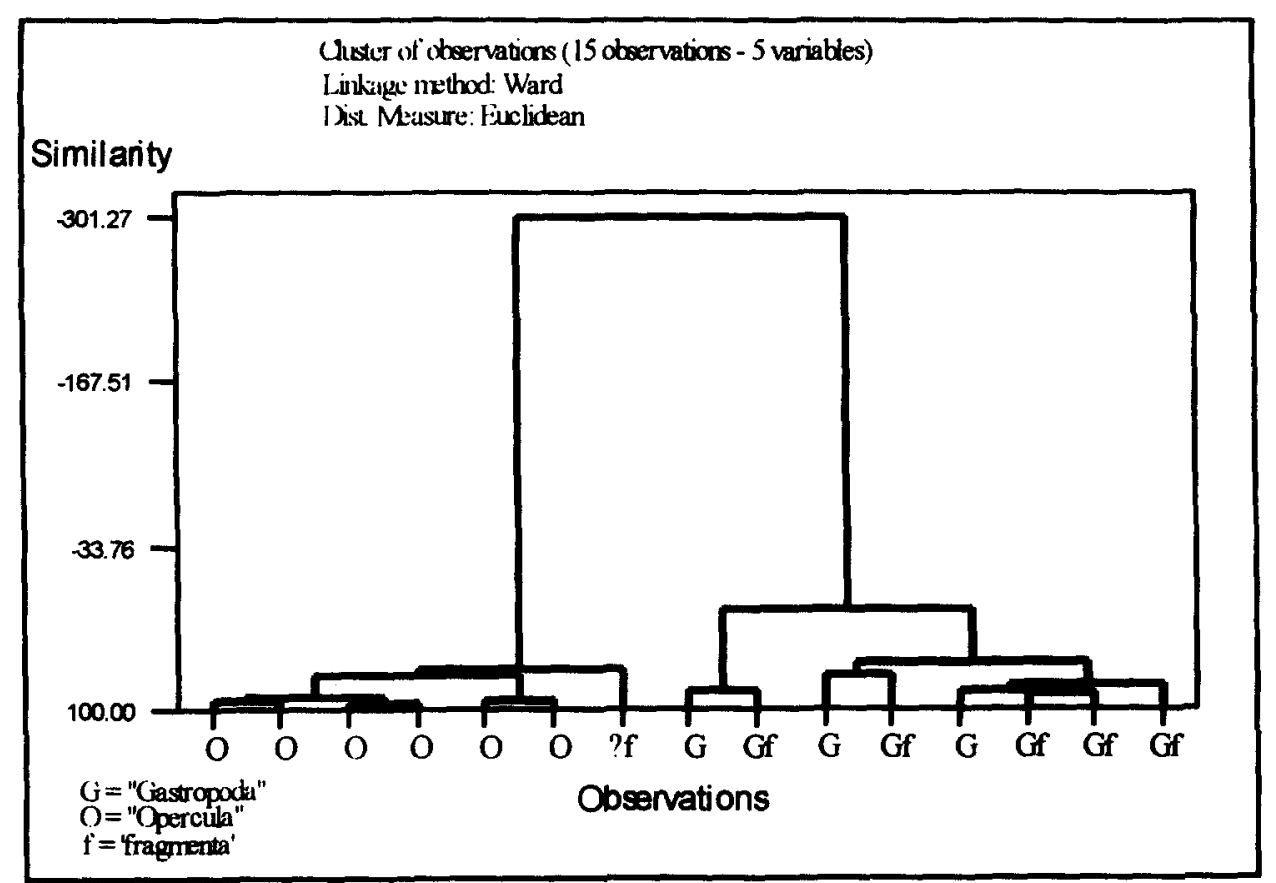

Fig. 5. Similarity cluster of amino acid racemization ratios (Ile/Alo isoleucine, leucine, aspartic acid, glutamic acid) of Venta Micena samples.

remaining samples could be classed into two groups: Opercula and Gastropoda. The former were 2-3 mm sized, subcircular-ellipsoidal shaped dishes of aragonite, probably of Bithynia sp. Three different genera were grouped into Gastropoda.
First, a cluster analysis was performed with GC analysis results, three different groups being identified. One of these groups, which differed widely from the other two, included four samples with very low racemization rates, this disagreeing with

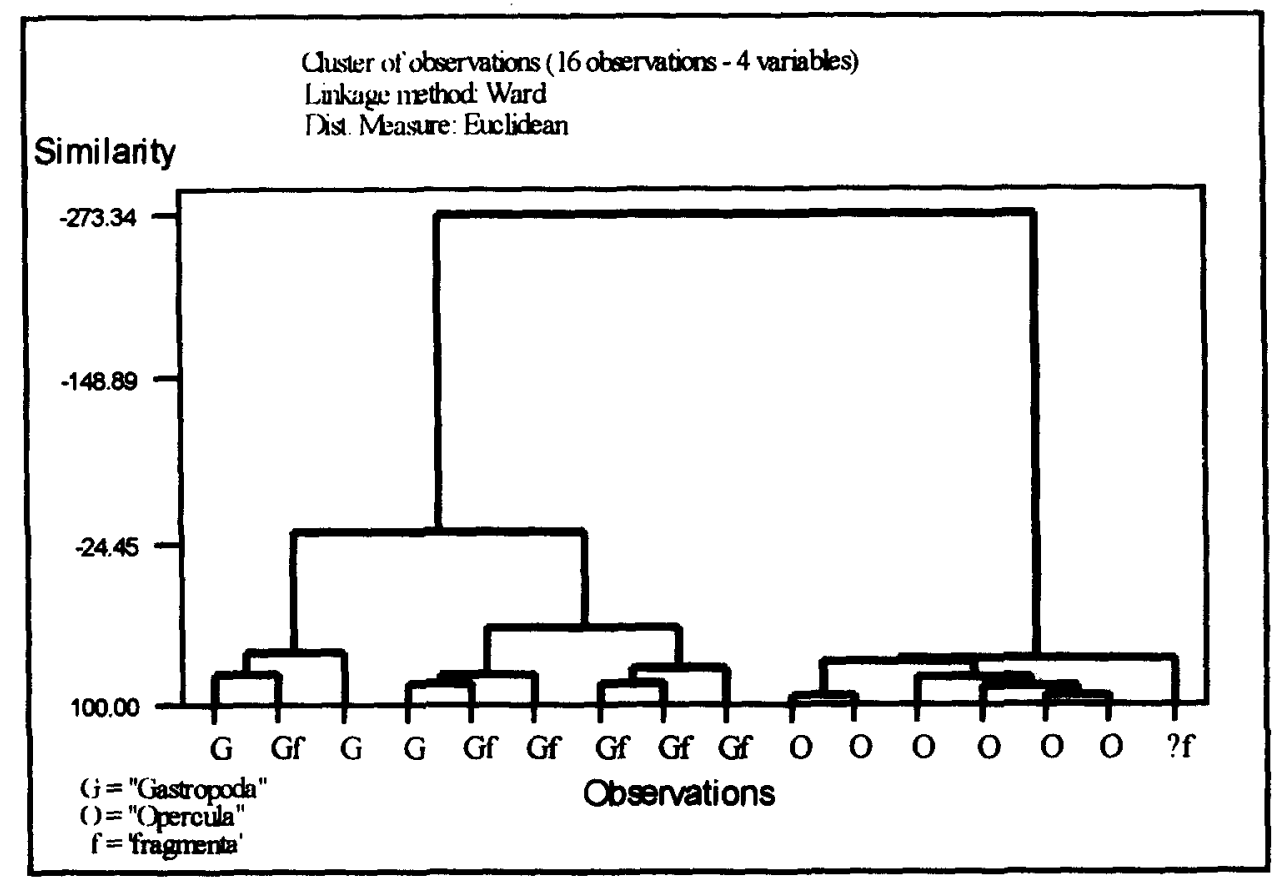

Fig. 6. Similarity cluster of amino acid racemization ratios (Ile/Alo isoleucine, leucine, aspartic acid, phenilalanine, glutamic acid) of Venta Micena samples. 


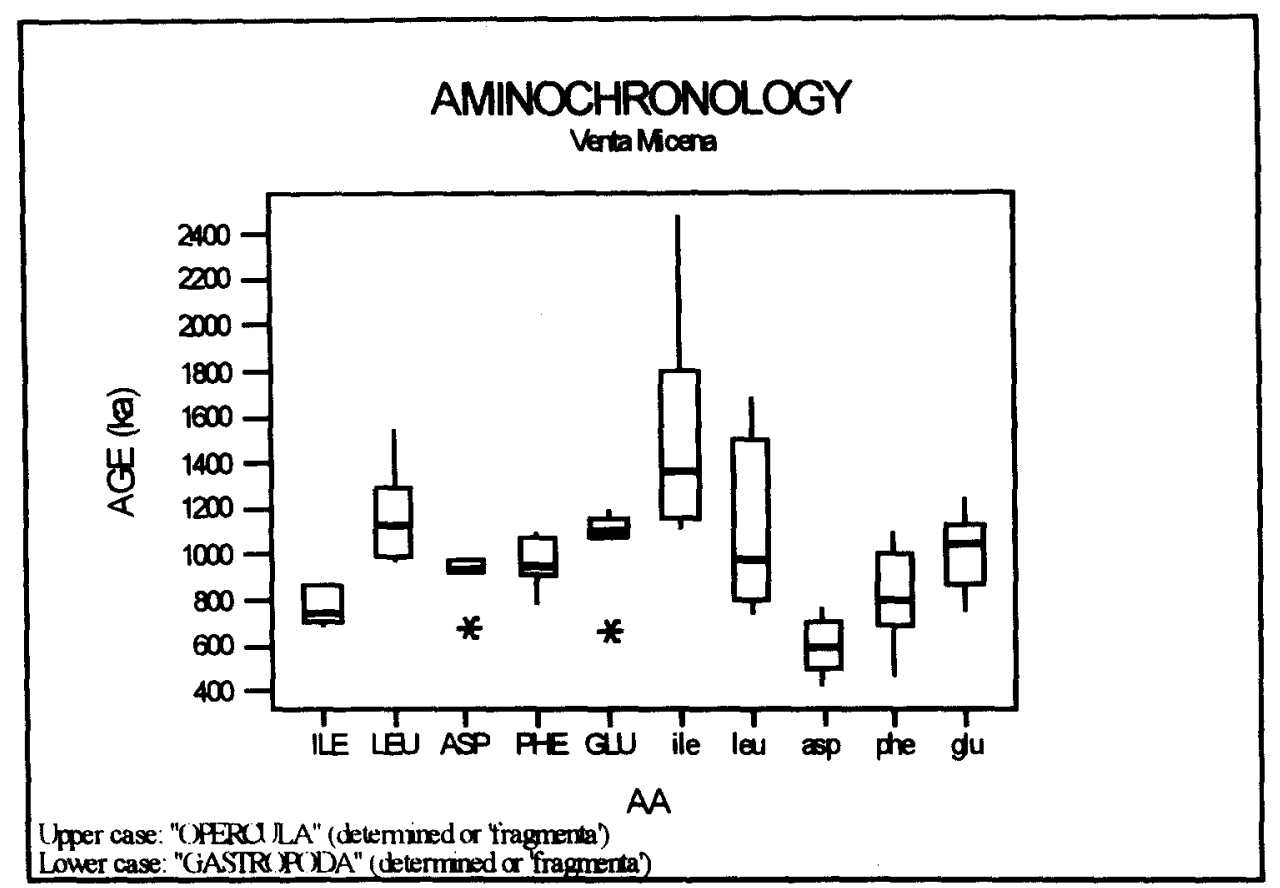

Fig. 7. Box and whisker plot of calculated ages from different amino acids and materials from Venta Micena.

the other two. These results were interpreted as being due to the influence of contamination, and were discarded. A second cluster analysis of the 17 remaining samples revealed the existence of two groups: Opercula, along with an unidentified fragmenta, and Gastropoda (two Radix sp., one Bulimus sp. and six unidentified gastropod fragmenta). In the second group a fragmenta sample presented very low racemization ratios, with the exception only of Alo/Ile. This result has been interpreted as a diagenetic effect and was also discarded prior to performance of the final cluster analysis (Fig. 5). All the analyses were carried out on the basis of four amino acids (Alo) lle, leucine, aspartic acid and glutamic acid) since some results for phenylalanine were missing. When the clustering was accomplished using complete results, phenylalanine included, the grouping obtained was the same (Fig. 6), thus reinforcing the validity of the previous cluster analysis.
Final age calculation was accomplished according to the first set of models for seven samples grouped into Opercula, and according to the second set of models for nine samples included in the Gastropoda group (Fig. 7 and Table 3). The unidentified fragmenta was included in the Opercula group, this giving rise to a slight difference with respect to previously published data (Torres et al., 1995).

Taking into account the fact that the results obtained are independent measurements of the same parameter over a time interval, it is possible to calculate a global dating for each group (Table 3); it may be observed that age calculations for the fragmenta group show a higher scattering than those for the Opercula group. Prior to computing a "general average dating", the former global results from (Table 3) were analysed for each sample group, Opercula and Gastropoda. The test of the homogeneity of variances for the two groups shows that both are different, according to the

Table 3. D/L average values and age calculations of Venta Micena samples

\begin{tabular}{lcccccc}
\hline & A/I & LEU & ASP & PHE & GLU & GLOBAL \\
\hline & & & Opercula & & & \\
D/L & $1.160 \pm 0.031$ & $0.893 \pm 0.017$ & $0.922 \pm 0.012$ & $0.896 \pm 0.013$ & $0.835 \pm 0.033$ & \\
Age (Ky) & $778 \pm 66$ & $1174 \pm 149$ & $947 \pm 18$ & $909 \pm 78$ & $1062 \pm 138$ & $976 \pm 65$ \\
& & & Gastropoda & & $0.613 \pm 0.025$ & \\
D/L & $0.873 \pm 0.055$ & $0.881 \pm 0.043$ & $0.803 \pm 0.023$ & $0.706 \pm 0.043$ & 0.613 & $1009 \pm 130$ \\
Age (Ky) & $1511 \pm 318$ & $1111 \pm 258$ & $591 \pm 77$ & $809 \pm 144$ & $1012 \pm 107$ & \\
\hline
\end{tabular}




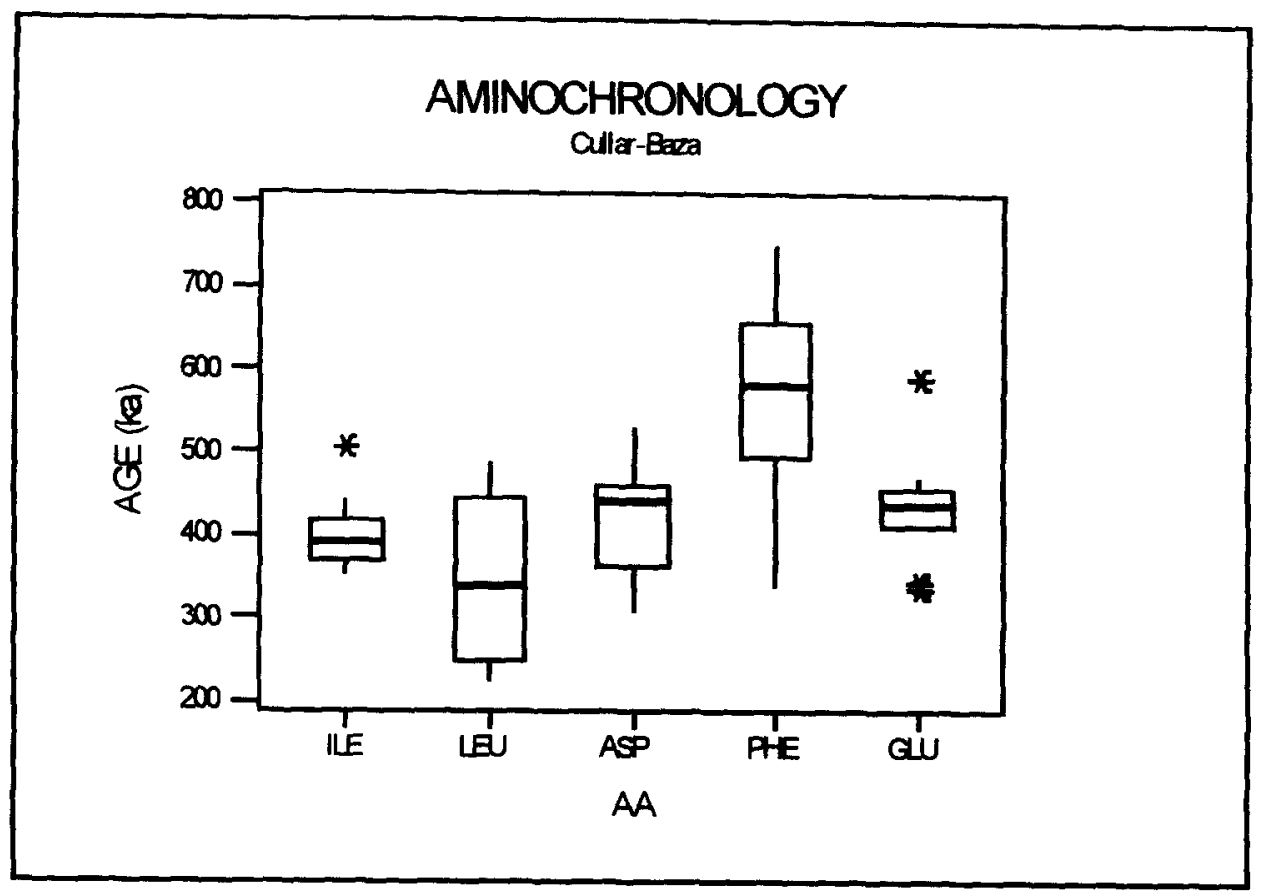

Fig. 8. Box and whisker plot of calculated ages from different amino acids and materials from Cúllar Baza.

Levene tests ( $p$ value $=0.002$ ). The test for the equality of the means, taking into account the nonhomogeneity of variance, demonstrates that the non-equability hypothesis cannot be rejected $(p=0.65)$.

To estimate the global mean from the means of the two sample groups, Opercula $(1001 \mathrm{Ky})$ and Gastropoda $(933 \mathrm{Ky})$, a weighted average has been calculated using the inverse of variances (1043 and $4212 \mathrm{Ky}^{2}$ ) as weighting factors. The result obtained was $983 \mathrm{Ky}$, with a variance of $836 \mathrm{Ky}^{2}$ ( $983 \pm 58 \mathrm{Ky}$ for the $95 \%$ confidence interval).

\section{Cúllar-Baza}

Fifteen Gastropoda samples were analysed (14 Helix sp. and one Planorbis sp.); one of them was lost during the sample preparation process. The cluster analysis of the $G C$ results and $D / L$ ratios showed the existence of an isolated group, and an anomalous individual with lower $\mathrm{D} / \mathrm{L}$ ratios for all the amino acid pairs identified, this being rejected. Final dating was calculated from the 13 remaining sample results. According to our own experience (Torres et al., 1995), the amino acid racemization kinetics of the Helix genus could assimilated to the first model set; calculations performed using the inadequate model set produced incoherent results, the only exception being leucine. Dating calculations were performed from each amino acid $\mathrm{D} / \mathrm{L}$ pair, see Fig. 8, and with all of them grouped. An age of $441 \pm 27 \mathrm{Ky}$ was obtained (Table 4).

\section{CONCLUSIONS}

The AARD method worked accurately in the Guadix-Baza basin: the data obtained are located on the chronostratigraphical levels assumed (using classical palaeontological methods) or slightly younger. An Upper Villafranchian geological age (Middle Biharian or 31 oxygen isotopic stage) may clearly be assumed for the Venta Micena palaeontological site; likewise, the Lower Villafranchian situation of the Venta Micena fauna remains may be entirely rejected. The dating of the Cúllar-Baza site,

Table 4. $D / L$ average values and age calculations of Cúllar-Baza samples

\begin{tabular}{lcccccc}
\hline & A/I & LEU & ASP & PHE & GLU & GLOBAL \\
\hline Helix D/L & $0.828 \pm 0.030$ & $0.610 \pm 0.054$ & $0.809 \pm 0.016$ & $0.799 \pm 0.027$ & $0.633 \pm 0.019$ & \\
Age (Ky) & $399 \pm 23$ & $351 \pm 64$ & $421 \pm 36$ & $569 \pm 66$ & $435 \pm 34$ & $441 \pm 21$ \\
\hline
\end{tabular}




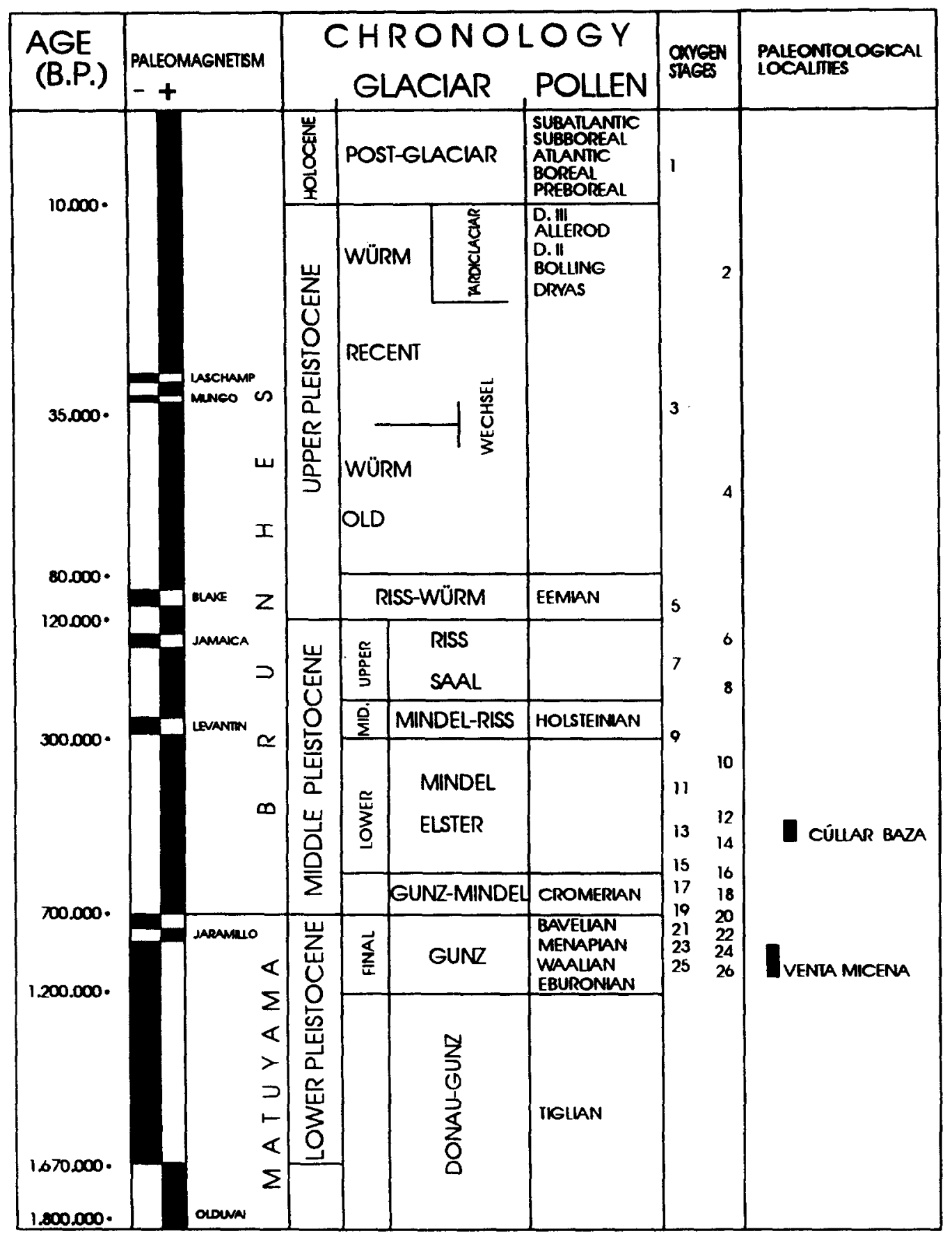

Fig. 9. Chronostratigraphical situation of Venta Micena and Cúllar Baza localities.

Middle Pleistocene (Upper Biharian, Mindel or 1213 oxygen isotopic stages), was also coherent (Sese, 1993), and certifies the validity of the Venta Micena dating fit. The results are summarized in (Fig. 9).

Acknowledgements - This study has been partially sup ported by UPM-ENRESA contract no. 0701041 "Datación de Formaciones Cuaternarias a partir de aminoácidos" (Dating of Quaternary Formations on the basis of amino acids). Cúllar-Baza site dating was obtained from the Project "Mapa Geológico Nacional de España
1:50000" of the Instituto Tecnológico Geominero de España.

\section{REFERENCES}

Abelson P. H. (1954) Organic constituents of fossils. Carnegie Inst. Wash. Yb. 53, 97-101.

Agusti J, (1984) Synthèse biostratigraphique du PlioPléistocene de Guadix-Baza (province de Granada, Sudest de l'Espagne). Geobios 19, 505-510.

Augstí J., Moya-Solá S., Martín E. and Marín M. (1987) Faunas de mamíferos en el Pleistoceno inferior de la 
región de Orce (Granada, España). In Geologia y Paleontologia del Pleistoceno Inferior de Venta Micena. Pal $i$ Evol. Mem. esp. 1, pp. 73-86.

Alberdi M. T., Alcalá L., Azanza B., Cerdeño E., Mazo A. V., Morales J. and Sesé C. (1989) Consideracione Biostratigráficas sobre la fauna de vertebrados fósiles de la Depresión de Guadix-Baza (Granada, España). In Geologia y Paleontologia de la Cuenca de Guadix-Baza (Edited by Alberdi M. T. and Bonadonna F. P.), CSIC. Trab. Neog. Cuat. Mus. Nac. Ci. Nats. 11, 347-355.

Anadón P., Juliá R., De Dekker P., Rosso J. C. and Soulié-Märsche I. (1987) Contribución a la paleolimnología del Pleistoceno inferior de la cuenca de Baza (Sector Orce-Venta Micena). In Geologia y Paleontología del Pleistoceno inferior de Venta Micena (Edited by Agustí J.). Itto. Pal. Miquel Crusafont Mem. Esp. I, 35-72.

Bada J. L. (1985) Racemization of amino acids. In Chemistry and Biochemistry of Amino Acids. (Edited by Barret, G. C.), pp. 399-414.

Bada J. L. and Schroeder R. A. (1972) Racemization of isoleucine in calcareous marine sediments: kinetics and mechanisms. Earth Planet. Sci. Lett. 15, 1-11.

Bada J. L. and Protchs H. (1973) Racemization of aspartic acid and its use in dating fossil bones. Natl Acad. Sci. Proc. 70, 1331-1334.

Bada J. L., Kvenvolden K. A. and Peterson E. (1973a) Racemization of amino acids in bones. Nature 245 , 308-310.

Bada J. L., Protchs H. and Schroeder R. (1973b) The racemization reaction of isoleucine used as palaeotemperature indicator. Nature 241, 394-395.

Dumas B., Gueremy P., Hearty P. J., Lhenaff R. and Raffy J. (1988) Morphometric analysis and amino acid geochronology of uplifted shorelines in a tectonic region near Reggio Calabria, South Italy. Palaeogeogr. Palaeoclimat. Palaeoecol. 68, 273-289.

Elster H., Gil-Av E. and Weiner S. (1991) Amino acid racemization of fossil bone. J. Arch. Sci. 18, 605-617.

Gibert J., Campillo D., Ribot F., Fernández C., Martínez B. and Caporicci R. (1989) Anatomical study; comparison of the hominid cranial fragment from Venta Micena (Orce, Spain) with fossil and extant mammals. Hum. Evol. 4, 283-305.

Gibert J., Iglesias A., Maillo A. and Gibert L. (1992) Industrias liticas en el Pleistoceno inferior de la región de Orce. In Presencia humana en el Pleistoceno inferior de Granada y Murcia (Edited by Gibert J.), pp. 219 281. Ayuntamiento de Orce, Granada.

Gibert J., Arribas A., Martínez B., Albadalejo S., Gaete R., Gibert L., Peñas C. and Torrico R. (1992) Sintesis cronoestratigráfica del Pleistoceno inferior de la región de Orce. In Presencia Humana en el Pleistoceno inferio de Granada y Murcia, Ayuntamiento de Orce (Granada) (Edited by Gibert J.), pp. 107-114. Ayuntamiento de Orce, Granada.

Goodfriend G. A. (1987) Chronostratigraphic studies of sediments in the Negev desert, using amino acid epimerization analysis of land snail shells. Quat. Res. 28, 374392

Goodfriend G.A. (1991) Patterns of racemization end epimerization of amino acids in land snail shells over the course of the Holocene. Geochim. Cosmochim. Acta 55, 293-302.

Goodfriend G. A. and Mitterer R. M. (1988) Late Quaternary land snails from the north coast of Jamaica: local extinctions and climatic change. Palaeogeogr. Palaeoclimat. Palaeoecol. 63, 293-311.

Goodfriend G. A. and Meyer V. (1991) A comparative study of the kinetics of amino acid racemization/epimerization in fossil and modern mollusc shells. Geochim Cosmochim. Acta 55, 293-302.
Hare P. E. (1969) Geochemistry of proteins, peptids and amino acids. In Organic Geochemistry; Methods and Results (Edited by Eglinton G. and Murphy M. T. J.). pp. 438-463. Springer, New York.

Hare P. E. (1971) Effect of hydrolysis on the racemization rate of amino acids. Carnegie Inst. Wash. Yb. 70, 256258

Hearty P. J., Vacher H. L. and Mitterer R. M. (1992) Aminostratigraphy and ages of Pleistocene limestones of Bermudas. Geol. Soc. Am. Bull. 104, 471-480.

Instituto Tecnológico Geominero de España (ITGE) (1989). Quaternary Map of Spain. Ministerio de Industria y Energía.

Kaufman D. S. (1992) Aminostratigraphy of PliocenePleistocene high sea levels, Nome coastal plain and adjacent nearshore area, Alaska. Geol Soc. Am. Bull. 104, 40-52.

Lauritzen S. E., Haugen J. E., Lovlie R. and Gilje-Nielsen H. (1994) Geochronological potential of isoleucine epimerization in calcite speleothemes. Ouat. Res. 41, 52-58.

Leive L. L. and Davis B. (1980) Cell envelope; Spores. In Microbiology (Edited by Davis B., Dulbecco R., Eisen H. N. and Ginsberg H. S.). pp. 71-110. Harper and Row, New York.

Llamas J. F., Torres T., García Alonso P., García Cortés A., Mansilla H., Meyer V. and Nodal T. (1995) Aminocronología de los depósitos del Pleistoceno medio de Redueña, Madrid. Geogaceta 17, 43-45.

Marzin E. (1990) Essai de normalisation du protocole d'analyse des taux de racémisation des acides aminés: applications a la datation d'ossements fossiles. Trav. du LAPMO, Université de Provence, pp. 167-178.

Meyer V. (1992) Amino acid racemization: a tool for fossil dating. Chemtech. 12, 412-417.

Miller G. H. and Hare P. E. (1975) Use of amino acid reactions in some marine fossils as stratigraphic and geochronologic indicators. Carnegie Inst. Wash. Yb. 74, 612-617.

Miller G. H. and Hare P. E. (1980) Amino acid geochronology: integrity of the carbonate matrix and potential of molluscan fossils. In Biogeochemistry of Amino Acids (Edited by Hare P. E., Hoering T. C. and King K., Jr.). pp. 415-444. Wiley, New York

Miller G. H. and Mangerud J. (1985) Aminostratigaphy of European marine interglaciar deposits. Quat. Sci. Rev. 4, 215-278.

Mitterer R. (1975) Ages and diagenetic temperatures of Pleistocene deposits of Florida based upon isoleucine epimerization in Mercenaria. Earth Planet Sci. Lett. 28, 275-282.

Robles F. (1987) Moluscos continentales del PlioPleistoceno de la cuenca de Guadix-Baza. In Geología y Paleontología de la Cuenca de Guadix-Baza. (Edited by Alberdi M. T. and Bonadonna F. P.). Trab. Neog. Cuat. Mus. Nal. Cas. Nats. CSIC 11, pp. 127-138.

Rutter N. W. and Vlahos K. C. (1988) Amino acid racemization kinetics in wood; applications to geochronology and geothermometry. In Dating Quaternary Sediments (Edited by Easterbrook J.), Geol. Soc. Am. Spec. Paper 227, 51-68.

Schroeder R. A. and Bada J. L. (1976) A review of the geochemical applications of the amino acid racemization reaction. Earth-Science Reviews 12, 347-391.

Sesé C. (1993) Reconstrucción paleoambiental del final del Plioceno y del Pleistoceno en España a través de los micromamiferos. In Sintesis del Medio Ambiente en España Durante los dos Últimos Millones de años CEC F12W-CT-91-0075 contract (Edited by Torres T.). pp. 319-342.

Soria F. J., López-Garrido A. C. and Vera J. A. (1987) Análisis estratigráfico y sedimentológico de los depósitos neógeno-cuaternarios en el sector de Orce 
(Depresión de Guadix-Baza). In Geologia $y$ Paleontologia del Pleistoceno Inferior de Venta Micena (Edited by Agustí J.). Itto. Pal. Miquel Crusafont Mem. Esp. 1, 11-34.

Torres T. (1995) Aminoestratigrafia y geocronologia por análisis de racemización de aminoácidos de muestras de gasterópodos y lamelibranquios de la cuenca de Cúllar-Baza Granada, Proyecto MAGNA (inedit report).

Torres T., Canoira L., Cobo R., Coello F. J., García P., Garcia-Cortés A., Hoyos M., Juliá R., Llamas J., Mansilla H. and Meyer V. (1994) Aminoestratigrafia y aminozonación de los travertinos fluviales de Priego (Cuenca, España Central). Geogaceta 16, 102 105.

Torres T., Llamas J., Canoira L., García-Alonso P., García-Cortés A. and Mansilla H. (1995) Amino chron- ology of the lower Pleistocene deposits of Venta Micena (Orce, Granada). In Organic Geochemistry: Developments and Applications to Energy, Climate, Environment and Human History (Edited by Grimalt J. O. and Dorronsoro C.). pp. 722-724. ALAGO, Donostia-San Sebastian.

Wehmiller J. F. (1984) Relative and absolute dating of Quaternary molluscs with amino acid racemization: evaluation, application, questions. In Quaternary Dating Methods (Edited by Mahaney W. C.). pp. 171-193. Elsevier, Amsterdam.

Wehmiller J. F. (1993) Applications of organic geochemistry for quaternary research. In Organic Geochemistry (Edited by Engel M. H. and Macko S. A), pp. 755-783. Plenum Press, New York. 